\title{
Linking genotype to phenotype with Bayesian network modeling of Chlamydia infection
}

\author{
Jesse D Ziebarth ${ }^{1 *}$, Bao Li ${ }^{1}$, Isao Miyairi ${ }^{1,2}$, Yan Cui ${ }^{1,3}$ \\ From UT-ORNL-KBRIN Bioinformatics Summit 2010 \\ Cadiz, KY, USA. 19-21 March 2010
}

\section{Background}

Understanding the causal pathways that link genotypes with gene expression and higher order phenotypes, such as disease susceptibility, has been a recent goal of systems genetic studies. Pairwise correlations can select genes and phenotypes that are associated with a common genetic locus; however, the directions of these links are more difficult to determine. We propose a method in which Bayesian networks are used to establish causal pathways from genotype to gene expression to phenotype and apply it to mice infected with Chlamydia psittaci.

\section{Results}

Recombinant inbred BXD mice strains have been previously used to study the genetic differences that cause a much greater resistance to Chlamydia psittaci infection in C57BL/6J mice compared with DBA/2J mice [1].

Gene expression levels and higher order phenotypes, such as pathogen load and survival, were collected for 44 BXD strains. Directed graphs linking SNPs [2] in the BXD genomes to this data were created with QTL mapping and the Bayesian network method. Figure 1 shows a selection of the resulting causal pathways; many of the genes in these pathways are known to be associated with immune response or GTPase activity, which has been linked to Chlamydia psittaci infection [1].

\section{Acknowledgements}

This work was support by NIH grant Al081050 and DOD grant W81XHW-0501-0227.

\section{Author details}

${ }^{1}$ Department of Molecular Sciences, University of Tennessee Health Science Center, Memphis, TN 38163, USA. ${ }^{2}$ Department of Pediatrics, University of Tennessee Health Science Center, Memphis, TN 38163, USA. ${ }^{3}$ Center of Integrative and Translational Genomics, University of Tennessee Health Science Center, Memphis, TN 38163, USA.

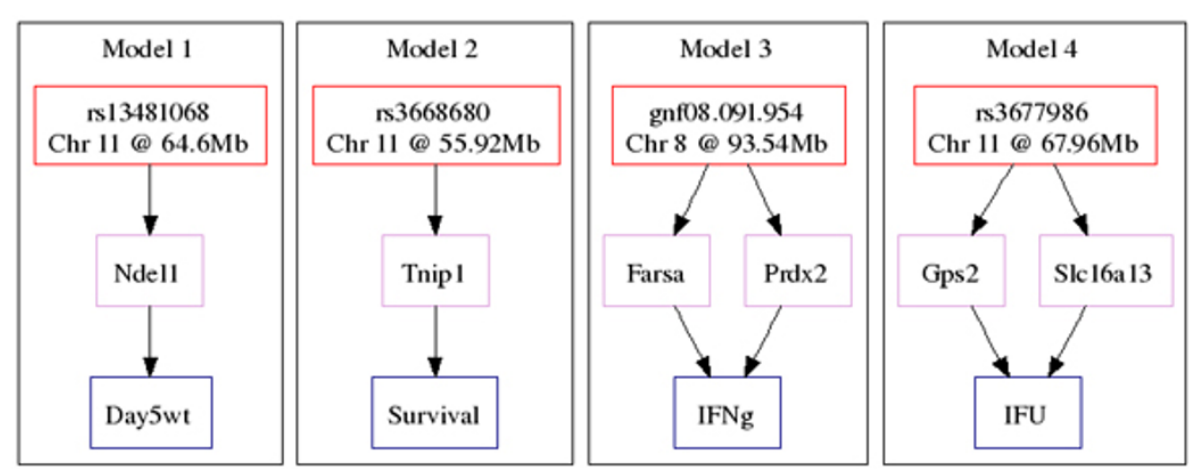

Figure 1 Causal pathways linking genotype SNPs to gene expression levels to phenotypes in BXD mice infected with Chlamydia psittaci

* Correspondence: jziebart@uthsc.edu

'Department of Molecular Sciences, University of Tennessee Health Science Center, Memphis, TN 38163, USA 
Published: 23 July 2010

\section{References}

1. Miyairi I, Tatireddigari VRRA, Mahdi OS, Rose LA, Belland RJ, Lu L, Williams RW, Byrne Gl: The p47 GTPases ligp2 and Irgb10 regulate innate immunity and inflammation to murine Chlamydia psittaci infection. J Immunol 2007, 179:1814-1824.

2. BXD Genotypes at the GeneNetwork. [http://www.genenetwork.org/ genotypes/BXD.geno].

doi:10.1186/1471-2105-11-S4-P19

Cite this article as: Ziebarth et al.: Linking genotype to phenotype with Bayesian network modeling of Chlamydia infection. BMC Bioinformatics 2010 11(Suppl 4):P19.

Submit your next manuscript to BioMed Central and take full advantage of:

- Convenient online submission

- Thorough peer review

- No space constraints or color figure charges

- Immediate publication on acceptance

- Inclusion in PubMed, CAS, Scopus and Google Scholar

- Research which is freely available for redistribution

Submit your manuscript at www.biomedcentral.com/submit
C Biomed Central 